\title{
Article/Artigo
}

\section{Seroprevalence of Helicobacter pylori infection in chagasic and non- chagasic patients from the same geographical region of Brazil}

\author{
Soroprevalência da infecção por Helicobacter pylori em indivíduos chagásicos e não-chagásicos \\ da mesma região geográfica do Brasil
}

\begin{abstract}
Fernanda Machado Fonseca ${ }^{1}$, Dulciene Maria de Magalhães Queiroz ${ }^{2}$, Andreia Maria Camargos Rocha ${ }^{2}$, Aluízio Prata $\uparrow$, Eduardo Crema ${ }^{3}$, Virmondes Rodrigues Junior ${ }^{1}$, Luiz Eduardo Ramirez ${ }^{1}$ and Adriana Gonçalves de Oliveira ${ }^{1}$
\end{abstract}

\section{ABSTRACT}

Introduction: In this study, we evaluated the seroprevalence of Helicobacter pylori infection among chagasic and non-chagasic subjects as well as among the subgroups of chagasic patients with the indeterminate, cardiac, digestive, and cardiodigestive clinical forms. Methods: The evaluated subjects were from the Triângulo Mineiro region, Minas Gerais, Brazil. Chagasic patients showed positive reactions to the conventional serological tests used and were classified according to the clinical form of their disease. Immunoglobulin $\mathrm{G}$ antibodies specific to $H$. pylori were measured using a commercial enzyme-linked immunosorbent assay kit. Results: The overall $H$. pylori prevalence was $77.1 \%(239 / 310)$ in chagasic and $69.1 \%(168 / 243)$ in non-chagasic patients. This difference was statistically significant even after adjustment for age and sex (odds ratio $=1.57 ; 95 \%$ confidence interval, $1.02-2.42 ; \mathrm{p}=0.04)$ in multivariate analysis. The prevalence of infection increased with age in the non-chagasic group $(p=$ $0.007, \chi^{2}$ for trend), but not in the chagasic group ( $p=0.15, \chi^{2}$ for trend). H. pylori infection was not associated with digestive or other clinical forms of Chagas disease $(p=0.27)$. Conclusions: Our findings demonstrate that chagasic patients have a higher prevalence of $H$. pylori compared to non-chagasic subjects; a similar prevalence was found among the diverse clinical forms of the disease. The factors contributing to the frequent co-infection with H. pylori and Trypanosoma cruzi as well as its effects on the clinical outcome deserve further study. Keywords: Helicobacter pylori. Chagas disease. Chronic Chagas disease clinical forms. Co-infection.

\section{RESUMO}

Introdução: No presente estudo, foi comparada a soroprevalência da infecção por Helicobacter pylori entre os indivíduos chagásicos e não-chagásicos, bem como entre subgrupos de chagásicos com as formas clínicas indeterminada, cardíaca, digestiva e cardiodigestiva. Métodos: Os indivíduos avaliados eram provenientes da região do Triângulo Mineiro, Minas Gerais, Brasil. Foram realizados testes sorológicos convencionais para diagnóstico da infecção pelo T. cruzi e os chagásicos foram classificados de acordo com a forma clínica. O diagnóstico de infecção por $H$. pylori foi estabelecido pela detecção de anticorpos IgG específicos utilizando-se um kit comercial de ELISA. Resultados: A prevalência da infecção por $H$. pylor foi $77,1 \%(239 / 310)$ no grupo de pacientes chagásicos e 69,1\% (168/243) no grupo de nãochagásicos. Esta diferença foi estatisticamente significativa mesmo após ajuste para idade e sexo $(\mathrm{OR}=1,57 ; 95 \% \mathrm{CI}, 1,02-2,42 ; \mathrm{p}=0,04)$ na análise multivariada. A prevalência da infecção aumentou de acordo com a idade no grupo não-chagásicos $\left(\mathrm{p}=0,007, \chi^{2}\right.$ for trend $)$ mas este aumento não foi observado no grupo dos chagásicos $\left(\mathrm{p}=0,15, \chi^{2}\right.$ for trend $)$. Não houve associação da infecção por $H$. pylori com a forma digestiva ou com qualquer outra forma clínica da doença de Chagas $(\mathrm{p}=0,27)$. Conclusões: Foi demonstrado que pacientes chagásicos apresentam maior prevalência da infecção por $H$. pylori quando comparados com não-chagásicos, independente da forma clínica da doença. Os fatores que contribuem para a frequente co-infecção Helicobacter pylori e Trypanosoma cruzi, bem como seus efeitos na evolução clínica das doenças associadas devem ser melhor estudados.

Palavras-chaves: Helicobacter pylori. Doença de Chagas. Formas clínicas da doença de Chagas crônica. Co-infecção.

1. Departamento de Ciências Biológicas, Universidade Federal do Triângulo Mineiro, Uberaba, MG. 2. Laboratório de Pesquisa em Bacteriologia, Faculdade de Medicina, Universidade Federal de Minas Gerais, Belo Horizonte, MG. 3. Departamento de Clínica Médica, Universidade Federal do Triângulo Mineiro, Uberaba, MG. $\dagger$ In memorian.

Address to: Dra. Adriana Gonçalves de Oliveira. DCB/UFTM. Praça Manoel Terra 330, 38015-050 Uberaba, MG, Brasil.

Phone: 5534 3318-5480; Fax: 5534 3318-5462.

e-mail: agoliveira@dcb.uftm.edu.br

Received in 18/06/2011

Accepted in 30/09/2011

\section{INTRODUCTION}

Chagas disease, a tropical disease strongly associated with poor socioeconomic conditions, is endemic in rural Latin America. However, cases of Chagas disease have been reported throughout the world in the past few decades due to the increase in migrations towards non-endemic countries ${ }^{1}$. An estimated 10 million people are infected, mostly in Latin America, with the causative agent Trypanosoma cruzi, which is mainly transmitted by blood-sucking triatomine bugs ${ }^{2}$.

The clinical course of Chagas disease is highly variable. In a substantial proportion of the individuals who survive the acute phase, the disease enters the chronic phase that generally starts with a long period of clinical latency called the indeterminate form, which lasts for 10-30 years or throughout life ${ }^{3}$. Approximately one-third of these infected patients will develop serious lesions in the heart and/or digestive tract, characterizing the other clinical forms of chronic Chagas disease (i.e., cardiac, digestive, or cardiodigestive).

Likewise, the gram-negative bacterium Helicobacter pylori persists in most individuals, after being acquired mainly in childhood, as a chronic infection throughout life without complications, although a small percentage of infected individuals will develop severe gastroduodenal disease. Currently, $H$. pylori infection is recognized as the main cause of chronic gastritis and is directly linked to the development of peptic ulcer disease as well as gastric carcinoma and MALT lymphoma ${ }^{4}$. Interactions between bacterial virulence, host-related and environmental factors influence the clinical outcome in infected individuals, whereas concurrent infection with other pathogens may also potentially exacerbate or reduce disease severity due to the modulation of the gastric inflammatory process ${ }^{5-8}$.

Before the discovery of $H$. pylori, the chronic gastritis commonly seen in chagasic patients, most 
often in those with the digestive form, had been formerly attributed to biliary duodenal-gastric reflux as well as to hypomotility and hypochlorhydria, resulting in injury to the enteric nervous system caused by $T$. cruzi infection ${ }^{9-12}$. Later, some studies demonstrated a high prevalence of $H$. pylori infection in patients with Chagas disease ${ }^{13-16}$. As this small number of studies on T. cruzi and H. pylori co-infection had no control groups and/or included a low number of patients, we evaluated the prevalence of $H$. pylori infection among chagasic and non-chagasic subjects living in a region previously considered endemic for Chagas disease. We also analyzed whether $H$. pylori infection is associated with the clinical forms of chronic Chagas disease.

\section{METHODS}

We evaluated outpatients with Chagas disease and subjects without the disease from the same geographical region living in a rural or urban area of Uberaba and other nearby cities. These cities are located in the west of the State of Minas Gerais, Brazil, in a region called Triângulo Mineiro, which was previously considered an endemic area for Chagas disease. Most of the study population was originally recruited to evaluate the prevalence of Chagas disease in the region. Therefore, the majority of the non-chagasic subjects were relatives of chagasic patients or were living near their residence. The other non-chagasic subjects were patients with dyspeptic complaints who underwent diagnostic endoscopy at the Hospital de Clinicas of the Universidade Federal do Triângulo Mineiro (UFTM). Peripheral blood $(5 \mathrm{~mL})$ was collected from the subjects into vacuum tubes for serological tests in the period from 1995-2010. The sample was centrifuged and the serum was divided into aliquots and stored in sterile containers at $-20^{\circ} \mathrm{C}$ before testing.

The presence of immunoglobulin ( $\mathrm{Ig}) \mathrm{G}$ antibodies specific to $H$. pylori was measured by using a commercial enzyme-linked immunosorbent assay (ELISA) kit (Pyloriset EIA-GIII; Orion Diagnostica, Espoo, Finland). The antigen employed in this kit is a cell surface protein of $H$. pylori strain NCTC 11637. The assay was performed according to the manufacturer's instructions. Patients with positive serology were considered to be infected with $H$. pylori because spontaneous elimination of this bacterium without a specific eradication therapy is a rare event. The concentrations of IgG antibody in serum samples were determined by interpolation from a standard curve constructed by plotting absorbance values obtained for each of the 4 calibrator sera, which are provided by the manufacturer, against the corresponding anti-H. pylori concentrations in $\mathrm{U} / \mathrm{mL}$.

The diagnosis of Chagas disease was performed by means of ELISA (Chagatest ELISA-WIENER, Argentina), hemagglutination (Chagatest HAI-WIENER, Argentina), and immunofluorescence (Imuno-Con Chagas-WAMA, Brazil) tests. All chagasic patients showed positive reactions to at least 2 serological tests, while non-chagasic subjects showed negative reactions to all 3 tests. Chagasic patients were classified according to the clinical form of their disease on the basis of the results of a conventional electrocardiogram and contrast X-ray of the esophagus and colon. Clinical, epidemiological, and demographic data were collected by reviewing the patients' medical records. Only patients for who complete data were available were included in this study.

Data were analyzed using the SPSS statistical software package (version 17.0; SPSS Inc., Chicago, IL, USA). The association between $H$. pylori infection and Chagas disease was evaluated using a logistic regression model. Variables such as gender and mean age were included in this analysis. The odds ratio (OR) as well as its $95 \%$ confidence interval (CI) were determined. The association between $H$. pylori infection and the clinical form of chronic Chagas disease was tested by the two-tailed $\chi^{2}$ test with Yates correction or Fisher's exact test. To evaluate the prevalence of $H$. pylori with aging, the $\chi^{2}$ test for trend was performed using Epi Info statistical software (version 3.5.1; Centers for Disease Control and Prevention, Atlanta, GA, USA). The significance level was set at $\mathrm{p} \leq 0.05$.

\section{Ethical considerations}

This study was carried out in accordance with the Declaration of Helsinki and was approved by the Ethics Committee of UFTM, Uberaba, State of Minas Gerais, Brazil.

\section{RESULTS}

A total of 553 subjects were included in the present study. Of these subjects, 310 (56.1\%) were patients with chronic Chagas disease (142 men and 168 women; mean age $57.7 \pm 12.6$ years, range 20-90) and 243 (43.9\%) were non-chagasic subjects (100 men and 143 women; mean age $42.4 \pm 15.9$ years, range $18-86)$. Among the 310 patients with Chagas disease, $106(34.2 \%)$ had the indeterminate clinical form of disease, 102 (32.9\%) had the cardiac form, 72 (23.2\%) had the digestive form, and 30 (9.7\%) had the cardiodigestive form.

The overall prevalence of $H$. pylori infection was significantly higher in chagasic $(77.1 \% ; 239 / 310)$ than in non-chagasic $(69.1 \%$; $168 / 243$ ) subjects, even after adjustment for age and sex (OR = 1.57; 95\% CI, 1.02-2.42; p = 0.04) in multivariate analysis (Table 1).

Table 2 shows that the prevalence of $H$. pylori infection increased with age ( $\mathrm{p}=0.007, \chi^{2}$ for trend) from $61.9 \%$ (18-29-years age group) to $81.6 \%$ (50-59-years age group) in the non-chagasic group, but not in the chagasic group ( $\mathrm{p}=0.15, \chi^{2}$ for trend). The rate of H. pylori infection decreased after 60 years of age among the non-chagasic subjects.

Figure 1 shows the prevalence of $H$. pylori infection according to the clinical forms of chronic Chagas disease. The rates of H.pylori positivity were $79.2 \%$ (84/106) in the group of patients with the cardiac form of the disease, $77.5 \%(79 / 102)$ in those with the indeterminate form, $76.7 \%$ (23/30) in those with the cardiodigestive form, and $73.6 \%$ (53/72) in those with the digestive form. There was no significant association between $H$. pylori infection and the clinical forms of Chagas disease $(\mathrm{p}=0.27)$.

There was no significant difference $(\mathrm{p}=0.34)$ in the concentrations of anti-H. pylori IgG for the chagasic (mean, $260.1 \mathrm{U} / \mathrm{mL}$ ) and nonchagasic (mean, $274.1 \mathrm{U} / \mathrm{mL}$ ) subjects. The mean concentration of antiH. pylori IgG was also similar $(\mathrm{p}=0.54)$ among the subgroups of patients with Chagas disease: digestive $(278.1 \mathrm{U} / \mathrm{mL})$, indeterminate (mean, $267.3 \mathrm{U} / \mathrm{mL})$, cardiac $(247.5 \mathrm{U} / \mathrm{mL})$, and cardiodigestive $(239.5 \mathrm{U} / \mathrm{mL})$.

TABLE 1 - Variables associated with Helicobacter pylori infection in univariate and multivariate analysis.

\begin{tabular}{|c|c|c|c|}
\hline \multirow[b]{2}{*}{ Variables } & \multirow{2}{*}{$\begin{array}{c}\text { Univariate } \\
\text { analysisp value }\end{array}$} & \multicolumn{2}{|c|}{ Multivariate analysis } \\
\hline & & OR (95\% CI) & p value \\
\hline Age & 0.57 & - & - \\
\hline Gender & 0.57 & - & - \\
\hline Chagas disease & 0.03 & $1.57(1.02-2.42)$ & 0.04 \\
\hline
\end{tabular}


TABLE 2 - Prevalence of Helicobacter pylori infection in chagasic and non-chagasic patients according to age group.

\begin{tabular}{|c|c|c|c|c|c|c|}
\hline \multirow[b]{2}{*}{ Patients } & \multicolumn{5}{|c|}{ Number (\%) of H. pylori-positive individuals according to age group (years) } & \multirow{2}{*}{$\begin{array}{c}\chi^{2} \text { for trend } \\
\text { p value }\end{array}$} \\
\hline & 18-29 & 30-39 & 40-49 & $50-59$ & $\geq 60^{\mathrm{a}}$ & \\
\hline Chagasic & $5(83.3)$ & $19(82.6)$ & $37(86.0)$ & $64(72.7)$ & $114(76.0)$ & 0.15 \\
\hline Non-chagasic & 39 (61.9) & $35(63.6)$ & $41(82.0)$ & $31(81.6)$ & $22(59.5)$ & 0.007 \\
\hline
\end{tabular}

aThis age group was not included in the $\chi^{2}$ for trend analysis.

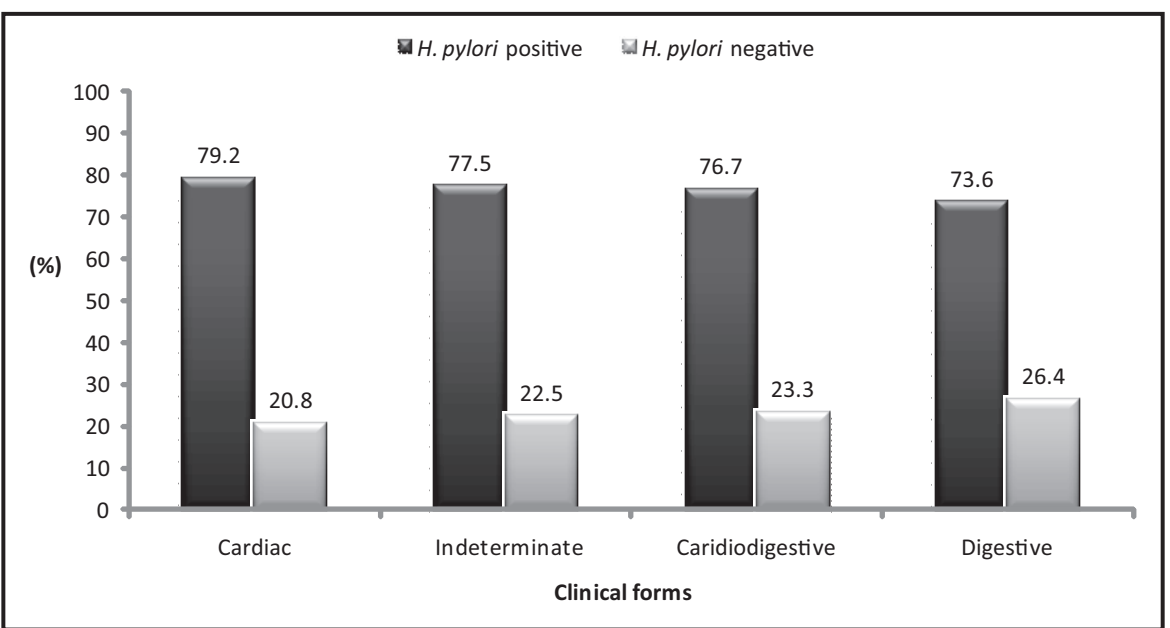

FIGURE 1 - Prevalence of Helicobacter pylori infection according to the clinical forms of chronic Chagas disease.

\section{DISCUSSION}

Approximately $50 \%$ of the world's population is estimated to be infected with $H$. pylori, but individuals living in countries with low socioeconomic conditions have high prevalence rates of $H$. pylori acquired at an early age ${ }^{4,17}$. In developing countries, individuals are also more susceptible to acquiring chronic concurrent infections with other pathogens; however, the co-infection prevalence is still largely unknown as are the effects of each other in the natural history of the infections.

After the discovery of $H$. pylori in 1982 , Barbosa et al. ${ }^{13}$ were the first to investigate the presence of bacteria in the gastric mucosa of patients with Chagas disease, followed by Oliveira et al., who evaluated patients with the digestive and indeterminate clinical forms of the disease, respectively. In those studies, the prevalence of H. pylori infection was very high ( $95 \%)$. It is worth noting that both were uncontrolled studies with a small number of patients. Later, Nascimento et al. found a significantly higher prevalence of $H$. pylori in chagasic patients aged 21-50 years compared with non-chagasic subjects living in the same urban or rural area. More recently, Pinazo et al. evaluated a short series of high-risk Latin American immigrants that lived in Barcelona, confirming the frequent coexistence of H. pylori and T. cruzi infections.

In the present study, in which a larger number of patients with chronic Chagas disease were evaluated, a significantly higher prevalence of $H$. pylori infection was found in the chagasic group compared to the non-chagasic group, even after adjustment for confounding factors such as age and gender in multivariate analysis. Considering that $H$. pylori, even with its multiple mechanisms for acid adaptation, is susceptible to acid and can only survive for a few minutes at the low $\mathrm{pH}$ of the stomach lumen ${ }^{8,18}$, we might speculate that the hypochlorhydria described in the digestive form of Chagas disease could contribute to the higher prevalence of $H$. pylori among these patients. However, no significant difference between patients with the digestive and non-digestive forms was observed. Although low gastric acid secretion has been demonstrated only in patients with the digestive form, to date, it is known that patients presenting with one of the clinical forms of chronic Chagas disease can also present with lesions in other systems due to the criteria currently used. For instance, severe impairment of the autonomic control of the heart may occur in patients apparently having only digestive tract involvement ${ }^{19}$. In addition, a variable number of chronic chagasic patients with the indeterminate form show structural or functional abnormalities of the heart and digestive tract when more accurate diagnostic tests are employed ${ }^{20-22}$. Taken together, these findings could explain why we found a higher prevalence of $H$. pylori infection in chagasic patients, but without differences among the different forms of the disease.

Conversely, as it is known that chronic $H$. pylori infection exerts profound and diverse effects on gastric acid secretion, one should consider the possibility that some gastric physiological alterations such as hypergastrinemia and hypochlorhydria that were originally attributed to Chagas disease $e^{9,23,24}$ may actually be exacerbated by concurrent $H$. pylori infection. The effects of $H$. pylori infection on the secretion of gastric acid depend on the degree and localization of the gastritis and are related to the disease outcome ${ }^{25}$. Briefly, $H$. pylori infection confined to the antrum results in antralpredominant gastritis with the hypersecretion of acid and is associated with duodenal ulceration, whereas body infection may result in atrophic gastritis and abnormally low gastric acid secretion.

In the present study, the prevalence of $H$. pylori infection increased with age among non-chagasic subjects aged $<60$ years of age, but not among chagasic patients, who showed relatively constant 
rates of infection regardless of age. Multiple epidemiological studies have shown that the prevalence of $H$. pylori increases with age, which is best explained by a cohort phenomenon with diminished acquisition during childhood as socioeconomic development has occurred, because the risk of acquiring the infection is considered to be low in adulthood ${ }^{4}$. Our data might indicate that patients with Chagas disease have a high risk for acquiring an $H$. pylori infection in childhood as well as in adult life. Moreover, as reported in other studies, we observed a decrease in the prevalence of infection among the oldest individuals, which has been explained by the fall in the specific serologic response among older individuals due to the decrease in their general immunity ${ }^{17,26-28}$.

Considering that the transmission of T. cruzi and H. pylori is associated with poor socioeconomic conditions, the high prevalence of co-infection with these pathogens found in our study ( $77 \%)$ is not surprising. In Brazil, the overall prevalence of $H$. pylori is high when compared to that of developed countries, although the rates found vary according to the geographical region studied. In the south of Brazil, the rate of $H$. pylori prevalence in adults is $\sim 63 \%$, while in the poorest regions such as the northeast and mid-west it is $\sim 90 \%^{27-29}$. Regarding the State of Minas Gerais, where the population evaluated in the present study lives, rates of $H$. pylori infection ranging from $62 \%$ to $86 \%$ have been reported among adults ${ }^{17,30}$. The study population of chagasic and non-chagasic subjects may be considered quite homogeneous since the majority of individuals were adults living in the same geographic region and, presumably, have similar socioeconomic conditions and risk factors for acquiring an $\mathrm{H}$. pylori infection.

In conclusion, our findings demonstrate that chagasic patients have a high prevalence of $H$. pylori compared to non-chagasic subjects in the study population. Notably, H. pylori infections were not associated with the digestive or other clinical forms of Chagas disease. Therefore, the factors contributing to this frequent co-infection with H. pylori and T. cruzi as well as the effects on the clinical outcomes deserve further study that will certainly contribute to a better understanding of the gastric physiological alterations induced by both of these important agents of chronic diseases.

\section{ACKNOWLEDGMENTS}

We thank Dr. Valdo José D. Silva for providing us with the clinical data of the chagasic patients with the cardiac form.

\section{CONFLICT OF INTEREST}

The authors declare that there is no conflict of interest.

\section{FINANCIAL SUPPORT}

This work was supported by grants from Fundação de Amparo à Pesquisa do Estado de Minas Gerais (FAPEMIG) and the Conselho Nacional de Desenvolvimento Científico e Tecnológico (CNPq), Brazil.

\section{REFERENCES}

1. Tanowitz HB, Weiss LM, Montgomery SP. Chagas disease has now gone global. PLSO Negl Trop Dis 2011; 5:e1136.

2. World Health Organization. Chagas disease (American trypanosomiasis) [Internet]. WHO Media centre; 2010 June. [Citation 2011 March 7]. Available from: http://www.who.int/mediacentre/factsheets/fs340/en/
3. Prata A. Clinical and epidemiological aspects of Chagas Disease. Lancet Infect Dis 2001 ; 1:92-100.

4. Brown LM. Helicobacter pylori: epidemiology and routes of transmission. Epidemiol Rev 2000; 22:283-297.

5. Fox JG, Beck P, Dangler CA, Whary MT, Wang TC, Shi HN, et al. Concurrent enteric helminth infection modulates inflammation and gastric immune responses and reduces Helicobacter-induced gastric atrophy. Nature Med 2000; 6:536-542.

6. Torres J, Perez GP, Ximenez C, Muñoz L, Camorlinga-Ponce M, Ramos F, et al. The association of intestinal parasitosis and H. pylori infection in children and adults from a Mexican community with high prevalence of parasitosis. Helicobacter 2003; 8:179-185.

7. Du Y, Agnew A, Ye XP, Robinson PA, Forman D, Crabtree JE. Helicobacter pylori and Schistosoma japonicum co-infection in a Chinese population: helminth infection alters humoral responses to $H$. pylori and serum pepsinogen I/II ratio. Microbes Infect 2006; 8:52-60.

8. Amieva MR, El-Omar EM. Host-bacterial interactions in Helicobacter pylori infection. Gastroenterol 2008; 134:306-323.

9. Troncon LEA, Oliveira RB, Meneghelli UG, Dantas RO, Godoy RA. Fasting and food-stimulated plasma gastrin levels in chronic Chagas' disease. Digestion 1984; 29:171-176.

10. Rezende JM, Rosa H, Vaz MGM, Andrade-Sá N, Porto JD, Neves Neto J, et al. Endoscopia no megaesôfago. Estudo prospectivo de 600 casos. Arq Gastroenterol $1985 ; 22: 53-62$

11. RomanelloLMF, Troncon LEA, Barbieri-NetoJ, Moreira AC, Oliveira RB, MódenaJLP. Níveis teciduais da prostaglandina 6-ceto-PGF 1á e integridade da mucosa gástrica em pacientes com doença de Chagas. Arq Gastroenterol 1991; 28:132-138.

12. Oliveira RB, Troncon LEA, Dantas RO, Meneghelli UG. Gastrointestinal manifestations of Chagas disease. Am J Gastroenterol 1998; 93:884-889.

13. Barbosa AJA, Queiroz DMM, Nogueira AMMF, Roquette Reis MJA, Mendes EN, Rocha GA, et al. Chronic gastritis and Helicobacter pylori in digestive form of Chagas' disease. Rev Inst Med Trop São Paulo 1993; 35:117-121.

14. Oliveira LCM, Buso AG, Siqueira Filho L, Moraes F, Oliveira HA, Oliveira RM, Salomão EC. Peptic disease and Helicobacter pylori are highly prevalent in patients with the indeterminate form of Chagas' disease: report of 21 cases. Rev Inst Med Trop São Paulo 1997; 39:209-212.

15. Nascimento RS, Valente SR, Oliveira LCM. Seroprevalence of Helicobacter pylori infection in chronic chagasic patients, and in the rural and urban population from Uberlândia, Minas Gerais, Brazil. Rev Inst Med Trop São Paulo 2002; 44:251-254.

16. Pinazo MJ, Elizalde JI, Posada EJ, Gascón J. Co-infection with two emergent old pathogens: Trypanosoma cruzi and Helicobacter pylori. Enferm Infecc Microbiol Clin $2010 ; 28: 751-752$.

17. Rocha GA, Rocha AMC, Silva LD, Santos A, Bocewicz ACD, Queiroz RM, et al. Transmission of Helicobacter pylori infection in families of preschool-aged children from Minas Gerais, Brazil. Trop Med Int Health 2003; 8:987-991.

18. Schreiber S, Bucker R, Groll C, Azevedo-Verthacke M, Garten D, Scheid P, et al. Rapid loss of motility of Helicobacter pylori in the gastric lumen in vivo. Infect Immun 2005; 73:1584-1589.

19. Sousa AC, Marin-Neto JA, Maciel BC, Gallo Júnior L, Barreto-Martins LE, Amorim DS. Use of isometric exercise to demonstrate cardiac parasympathetic impairment in the digestive form of Chagas' disease. Braz J Med Biol Res $1987 ; 20: 781-783$.

20. Moraes-Filho JPP, Moraes TABPP, Felix VN, Pereira-Barreto AC, Bettarello A Esophageal manometry and vectorcardiography study of asymptomatic patients with Chagas' disease. Rev Inst Med Trop São Paulo 1988; 30:406-410.

21. Ribeiro ALP, Rocha MOC. Indeterminate form of Chagas' disease: considerations about diagnosis and prognosis. Rev Soc Bras Med Trop 1998; 31:301-314.

22. Crema E, Oliveira RM, Werneck AM, Pastore R, Martins Júnior A Silva AA. Manometric evaluation of upper esophageal sphincter in patients with indeterminate form of Chagas disease. Rev Soc Bras Med Trop 2006; 39:156-158.

23. Padovan W, Godoy RA, Meneghelli UG, Dantas RO, Oliveira RB, Troncon LE. Acid and pepsin secretion in chronic chagasic patients in response to graded doses of pentagastrin and pentagastrin plus bethaconecol. Digestion 1982; 23:48-56.

24. Rocha JRM, Ribeiro U, Cecconello I, Sallum RAA, Takeda F, Nasi A, et al. Gastric secretory and hormonal patterns in end-stage chagasic achalasia. Dis Esophagus 2009; 22:606-610. 
25. McColl KEL, El-Omar E, Gillen D. Interactions between H. pylori infection, gastric acid secretion and anti-secretory therapy. Br Med Bul 1998; 54:121-138.

26. Torres J, Leal-Herrera Y, Perez-Perez G, Gomez A, Carmolinga-Ponce M, Cedillo-Rivera R, et al. A community-based seroepidemiologic study of Helicobacter pylori infection in Mexico. J Infect Dis 1998; 178:1089-1094.

27. Souto FJD, Fontes CJF, Rocha GA, Oliveira AMR, Mendes EN, Queiroz DMM. Prevalence of Helicobacter pylori infection in a rural area of the state of Mato Grosso, Brazil. Mem Inst Oswaldo Cruz 1998; 93:171-174.

28. Rodrigues MN, Queiroz DMM, Rodrigues RT, Rocha AMC, Braga Neto MB, Braga LLBC. Helicobacter pylori infection in adults from a poor community in northeastern Brazil: Demographic, lifestyle and environmental factors. Braz J Infect Dis 2005; 9:405-420.

29. Santos IS, Boccio J, Santos AS, Valle NCJ, Halal CS, Bachilli MC, et al. Prevalence of Helicobacter pylori infection and associated factors among adults in southern Brazil: a population-based cross-sectional study. BMC Public Health 2005; 5:118-127.

30. Rocha GA, Queiroz DMM, Mendes EN, Oliveira AM, Moura SB, Barbosa MT, et al. Indirect immunofluorescence determination of the frequency of anti-H. pylori antibodies in Brazilian blood donors. Braz J Med Biol Res 1992; 25:683-689. 